\title{
WHAT YOU NEED TO KNOW ABOUT VACCINATIONS
}

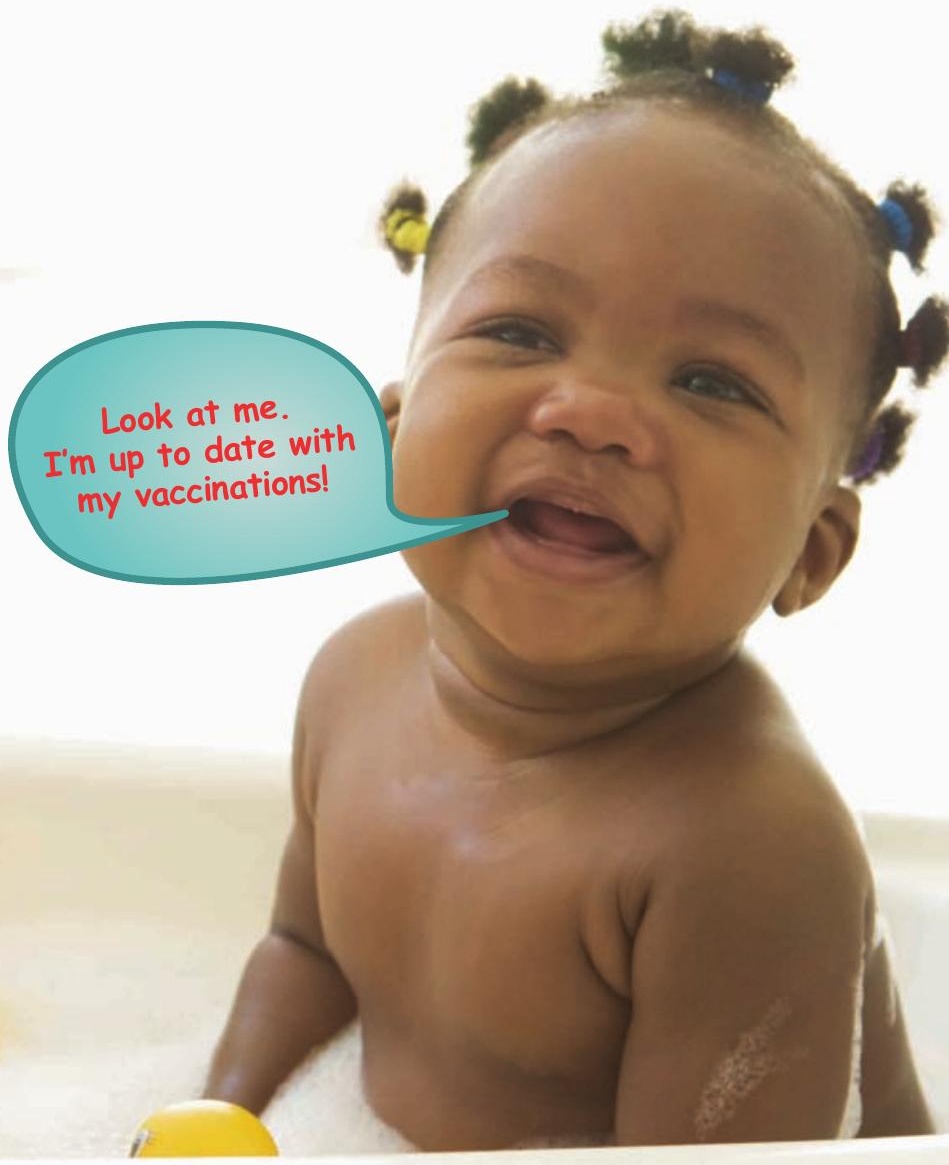

Brought to you by:

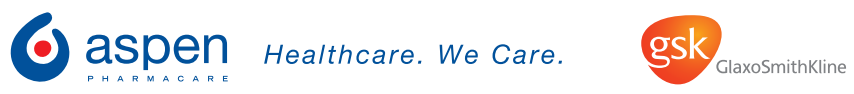

\section{health}




\section{ABOUT VACCINATIONS}

As a parent, you will want to know why vaccinating your child is important.

In the past, diseases such as smallpox and polio struck fear into the hearts of parents, as an infection in their child or community could mean death or paralysis. Today, thanks to the development of vaccines, smallpox has been totally eradicated and other infections such as polio and measles have nearly been eliminated. ${ }^{4}$

Why is it important for children to be vaccinated?

Children need to be vaccinated in order to protect them from certain infectious diseases. ${ }^{4}$

The Department of Health (DoH) is committed to improving the quality of primary healthcare in South Africa (SA) through various programs and initiatives. Despite enormous challenges, great strides have been made by the DoH to attain this objective. South Africa is the first country in Africa to introduce the Rotavirus and pneumococcal vaccines in its Expanded Program for Immunisation (EPI). This is viewed as a significant step towards achieving the millennium development goal (MDG4).

\section{What the Department of Health $(\mathrm{DoH})$ is doing for you and your community...}

- The DoH has accessible clinics for all South Africans

- The DoH provides free vaccinations to all infants and children up to the age of 12 years

- The DoH has recently introduced 2 NEW vaccines onto its Expanded Programme on Immunisation - EPI (SA), thereby providing infants with additional protection from infectious diseases ${ }^{4}$

- South Africa is the first country in Africa to introduce Rotavirus vaccine on its EPI

- This provides a healthy society for children to grow up in

\section{health}

Why should all children be vaccinated?

Vaccinations prevent the spread of disease within the community. ${ }^{5}$

Where do I go to have my child vaccinated?

Your local clinics and community health centres in South Africa will provide free vaccinations for your child. ${ }^{5}$

When should my child be vaccinated?

At birth, 6 weeks, 10 weeks, 14 Weeks, 9 months, 18 months, 6 years and at 12 years old. (See schedule on pages 6 and 7).

Does my child need to have all the vaccinations?

Yes, your child must have all the vaccinations on the attached schedule.

Which diseases will the vaccinations protect my child from? Tuberculosis, Polio, Rotavirus Gastroenteritis, Diphtheria, Tetanus, Whooping cough, Haemophilus Influenzae type B, Hepatitis B, Pneumococcal Infection, and Measles are the vaccinations that your child will be protected against. (More details of the above diseases to follow).

Are vaccinations safe?

As a result of medical research vaccinations are getting safer and more effective all the time. ${ }^{5}$

\author{
ALL PARENTS/GUARDIANS MUST \\ VACCINATE THEIR BABIES AND ADHERE \\ TO THE IMMUNISATION SCHEDULE
}




\section{TUBERCULOSIS (TB)}

TB is a contagious (disease spread by contact) infection that commonly affects the lungs. ${ }^{6}$ People with active TB often contaminate the air with bacteria when they cough or sneeze. ${ }^{6}$ These bacteria can stay in the air for several hours. If another person breathes the bacteria in, they may become infected. TB kills about 3 million people worldwide, every year. ${ }^{6}$

\section{Symptoms}

Coughing, night sweats and generally feeling unwell, with decreased energy and appetite are the most common symptom. ${ }^{6}$

\section{Why vaccinate?}

TB is a leading infectious cause of deaths in adults, killing about 1.5 million people every year. The BCG vaccination (given to prevent TB) is given to more than $80 \%$ of the world's children. ${ }^{7}$

\section{POLIOMYELITIS (POLIO)}

Polio is a highly contagious, viral infection that affects nerves and can produce permanent muscle weakness, paralysis and sometimes death. Polio is caused by a virus and is spread by digesting contaminated material. ${ }^{8}$

\section{Symptoms}

In the majority of polio infections there will be no symptoms. Of the infected people with symptoms, most will have mild symptoms including fever, headache, sore throat and vomiting. ${ }^{8}$

\section{Why vaccinate?}

Extensive vaccination has almost eradicated polio in developed countries. ${ }^{4}$ However, cases still occur in regions with incomplete vaccination such as sub-Saharan Africa and Southern Asia. ${ }^{9}$ The injectable polio vaccine given during childhood produces protection in more than $95 \%$ of recipients. ${ }^{9}$

\section{ROTAVIRUS GASTROENTERITIS}

Rotavirus is one of the most common causes of diarrhoea in children and spreads quickly and easily. 10,11 Rotavirus infects nearly every child before their $5^{\text {th }}$ birthday. ${ }^{10}$ Diarrhoea from rotavirus can quickly lead to dehydration. Dehydration can result in hospitalisation and even death for children who do not receive treatment in time. ${ }^{12,13}$

\section{Symptoms}

Symptoms begin with fever and vomiting, followed by watery diarrhoea, which typically lasts 5 to 7 days. If fluid losses are not replaced, dehydration develops. This makes the child weak and listless. ${ }^{11}$

\section{Why vaccinate?}

In South Africa approximately 6 children die every day from severe rotavirus. ${ }^{14,15}$ Worldwide, approximately 600000 children die each year from rotavirus. ${ }^{11}$ Rotavirus vaccination is now available at your local clinic for all infants older than six weeks and younger than 24 weeks of age.

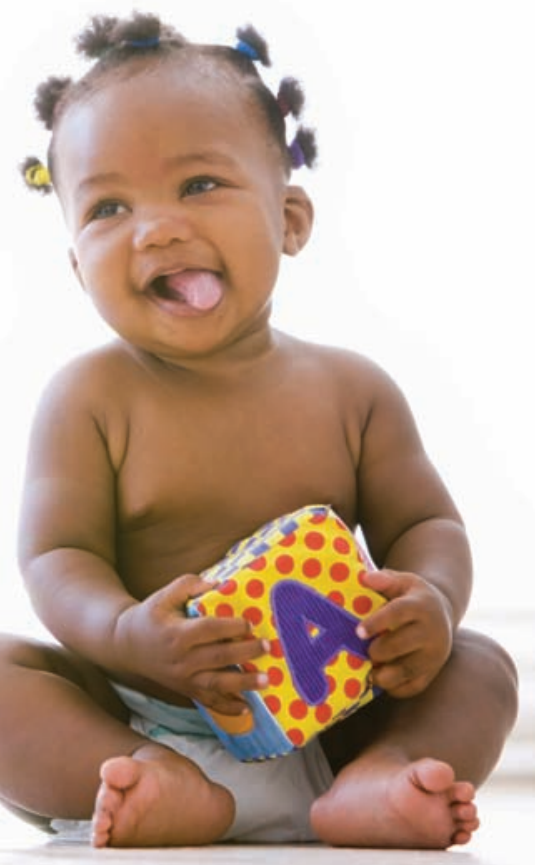




\begin{tabular}{|c|c|c|}
\hline Age of child & Vaccine needed & How and Where is it given? \\
\hline \multirow[t]{2}{*}{ At birth } & BCG Bacilles Calmette Guerin & Right arm \\
\hline & OPV (0) Oral Polio Vaccine & Drops by mouth \\
\hline \multirow[t]{5}{*}{6 weeks } & OPV (1) Oral Polio Vaccine & Drops by mouth \\
\hline & RV (1) Rotavirus Vaccine & Liquid by mouth \\
\hline & $\begin{array}{l}\text { DTap-IPV//Hib (1) Diphtheria, Tetanus, acellular Pertussis, } \\
\text { Inactivated Polio Vaccine and Haemophilus influenzae type b Combined }\end{array}$ & Intramuscular / Left thigh \\
\hline & Heb B (1) Hepatitis B Vaccine & Intramuscular / Right thigh \\
\hline & PCV7 (1) Pneumococcal Conjugated Vaccine & Intramuscular / Right thigh \\
\hline \multirow[t]{2}{*}{10 weeks } & $\begin{array}{l}\text { DTap-IPV//Hib (2) Diphtheria, Tetanus, acellular Pertussis, } \\
\text { Inactivated Polio Vaccine and Haemophilus influenzae type b Combined }\end{array}$ & Intramuscular / Left thigh \\
\hline & Heb B (2) Hepatitis B Vaccine & Intramuscular / Right thigh \\
\hline \multirow[t]{4}{*}{14 weeks } & RV (2) Rotavirus Vaccine* & Liquid by mouth \\
\hline & $\begin{array}{l}\text { DTap-IPV//Hib (3) Diphtheria, Tetanus, acellular Pertussis, } \\
\text { Inactivated Polio Vaccine and Haemophilus influenzae type b Combined }\end{array}$ & Intramuscular / Left thigh \\
\hline & Heb B (3) Hepatitis B Vaccine & Intramuscular / Right thigh \\
\hline & PCV7 (2) Pneumococcal Conjugated Vaccine & Intramuscular / Right thigh \\
\hline \multirow[t]{2}{*}{9 months } & Measles Vaccine (1) & Intramuscular / Left thigh \\
\hline & PCV7 (3) Pneumococcal Conjugated vaccine & Intramuscular / Right thigh \\
\hline \multirow[t]{2}{*}{18 months } & $\begin{array}{l}\text { DTap-IPV//Hib (4) Diphtheria, Tetanus, acellular Pertussis, } \\
\text { Inactivated Polio Vaccine and Haemophilus influenzae type b Combined }\end{array}$ & Intramuscular / Left arm \\
\hline & Measles Vaccine (2) & Intramuscular / Right arm \\
\hline 6 years (Both boys and girls) & Td Vaccine Tetanus and reduced strength of diphtheria Vaccine & Intramuscular / Left arm \\
\hline 12 years (Both boys and girls) & Td Vaccine Tetanus and reduced strength of diphtheria Vaccine & Intramuscular / Left arm \\
\hline
\end{tabular}




\section{DIPTHERIA}

Diphtheria is a contagious, sometimes fatal infection of the upper respiratory tract. ${ }^{16}$ The bacteria that cause diphtheria are usually spread in droplets of moisture coughed into the air. ${ }^{16}$

\section{Symptoms}

Symptoms include; sore throat, chills, general feeling of illness and fever. The lymph nodes in the neck may swell. ${ }^{16}$

\section{Why vaccinate?}

Diphtheria is readily preventable by means of vaccination. ${ }^{16}$ In children younger than 5 who are not vaccinated, the mortality rate can be as high as $20 \% .^{17}$

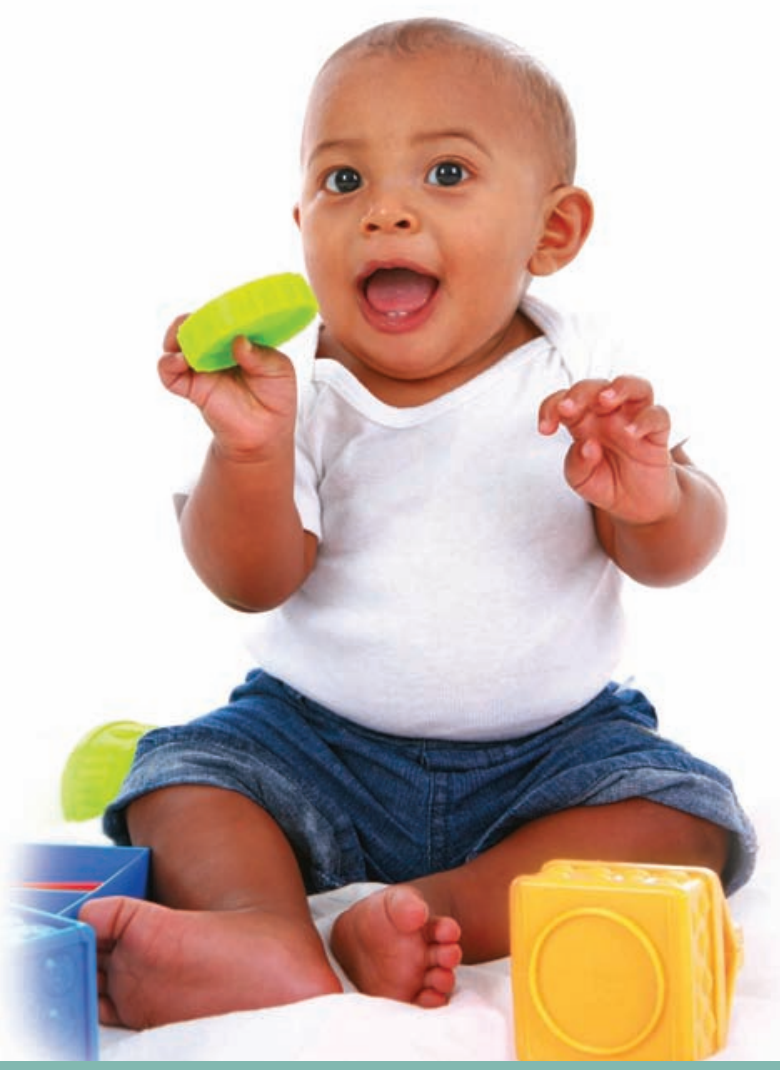

\section{TETANUS (LOCKJAW)}

Tetanus results from a toxin produced by the anaerobic bacteria Clostridium tetani. The toxin makes muscles become rigid and contract involuntarily. ${ }^{18}$ Tetanus bacteria may enter the body through wounds contaminated with soil or faeces and skin punctures. ${ }^{18}$

\section{Symptoms}

Muscles contract and become rigid. Spasms usually begin in the jaw and throat, followed by the neck, shoulder, face and then the abdomen and limbs. ${ }^{18}$

\section{Why vaccinate?}

Worldwide, about $50 \%$ of people who have tetanus die. ${ }^{18}$ Preventing tetanus is far better than treating tetanus. Tetanus rarely develops in people who have completed a primary series of tetanus vaccinations and have had vaccinations every 10 years as recommended. ${ }^{18}$

\section{PERTUSSIS (WHOOPING COUGH)}

Pertussis is a highly contagious infection caused by the bacteria Bordetella pertussis, which results in fits of coughing that usually end in a prolonged, high-pitched, deeply indrawn breath (the whoop). ${ }^{19}$

\section{Symptoms}

The disease is divided into 3 stages: ${ }^{19}$

- First stage - lasts for 1 or 2 weeks. Symptoms include mild cold like symptoms. (Sneezing, runny nose, hacking cough at night and a general feeling of illness)

- Second stage - lasts for 2 to 4 weeks. Coughing fits develop followed by the whoop. The cough often produces large amounts of thick mucous

- Third stage - lasts two to four weeks. Cough decreases and then stops

\section{Why vaccinate?}

Complications of pertussis can include pneumonia, ear infections and in rare instances brain damage. ${ }^{19}$ Active immunisation is part of the standard childhood vaccination schedule. 


\section{HAEMOPHILUS INFLUENZAE TYPE B (Hib)}

Haemophilus influenzae type B (Hib) can cause infection in the respiratory tract, which can spread to other organs. ${ }^{20}$ It spreads through the bloodstream and infects the joints, bones, lungs, skin, face, neck, eyes, urinary tract and other organs. ${ }^{20}$ These bacteria may cause two severe, often fatal infections: meningitis and epiglottitis. ${ }^{20}$ The bacteria are spread by an infected person sneezing or coughing respiratory droplets into the air, which are then inhaled by someone else. ${ }^{20}$

\section{Symptoms}

Symptoms depend on the part of the body affected. e.g. meningitis may present with fever, headache, stiff neck and vomiting. ${ }^{20}$

\section{Why vaccinate?}

Vaccines are available for children older than 6 weeks of age in South Africa and have decreased the incidence of serious infection by $99 \% .{ }^{21}$

\section{HEPATITIS B (HEP B)}

Hepatitis B is generally more serious than hepatitis $A$ and is occasionally fatal. Hepatitis B is also spread through contact with saliva, tears, breast milk, urine, vaginal fluid and semen. ${ }^{22}$

- A pregnant woman infected with hepatitis B can transmit the virus to her baby during birth. ${ }^{22}$

\section{Symptoms}

Symptoms can be mild or severe. They include decreased appetite, nausea, vomiting (acute) or as serious as fatal liver failure (Chronic). ${ }^{22}$

\section{Why vaccinate?}

Hepatitis B becomes chronic in 5 to $7 \%$ of people.22 The vaccine can prevent chronic hepatitis B in more than $80 \%$ of cases. ${ }^{22}$

\section{PNEUMOCOCCAL INFECTION}

Pneumococcal infections are caused by a gram-positive bacteria (pneumococcus). ${ }^{23}$ These bacteria are dispersed into the air when infected people cough or sneeze and are then inhaled by someone else. ${ }^{23}$ The most common infections caused by pneumococcus are pneumonia, meningitis, sinusitis and middle ear infections. ${ }^{23}$

\section{Symptoms}

Symptoms depend on the part of the body affected. The most common symptoms are fever, cough, headache, a general feeling of illness and ear pains. ${ }^{23}$

\section{Why vaccinate?}

Pneumococcal vaccines help protect against bacterial infections such as ear infections, sinusitis, pneumonia and meningitis. ${ }^{23}$

\section{MEASLES}

Measles is a highly contagious viral infection that is most common in children. ${ }^{24}$ It is spread mainly by airborne droplets of moisture coughed out by an infected person, or by touching items contaminated by such droplets. ${ }^{24}$ It is contagious for several days before and after the rash develops. ${ }^{24}$

\section{Symptoms}

The infected child first develops a fever, runny nose, hacking cough and red eyes. ${ }^{24}$ Tiny white spots appear inside the mouth followed by a sore throat. ${ }^{24} \mathrm{~A}$ mildly itchy rash appears 3 to 5 days after the start of symptoms. ${ }^{24}$ Starting around the ears and spreading to the trunk, arms and legs, the rash starts off as flat red areas that soon become raised. ${ }^{24}$ The child may develop a very high temperature $\left(40^{\circ} \mathrm{C}\right) .{ }^{24}$

\section{Why vaccinate?}

Worldwide, measles infects about 20 million people annually, causing about 200000 deaths, primarily in children..$^{25}$ Complications can be severe and include pneumonia, encephalitis (infection of the brain) and middle ear infections. ${ }^{24}$ 
References: 1. Vesikari T, Karvonen A, Prymula R, et al. Efficacy of human rotavirus vaccine against rotavirus gastroenteritis during the first 2 years of life in European infants: randomised,double-blind controlled study. Lancet 2007; 370: 1757-1763. 2. Ruiz-Palacios GM, Pérez-Schael I Velázquez FR, et al for the Human Rotavirus Vaccine Study Group. Safety and Efficacy of an Attenuated Vaccine against Severe Rotavirus Gastroenteritis. N Eng/ J Med 2006; 354:11-22. 3. Madhi SA, Lerumo T, Louw C, et al. Efficacy of Human Rotavirus Vaccine RIX4414 (Rotarix ${ }^{\mathrm{TM}}$ ) in South African Infants During the First Year of Life - an Interim Analysis. $8^{\text {th }}$ Rotavirus symposium 2008 - Istanbul, Turkey Available from:http://www.sabin.org/events/schedule/eight-international-rotavirussymposium-eventschedule Accessed 2704 2009. 4. Vaccinations: Newborns and Infants: Merck Manual Home Edition. Available at www.merck.com. Accessed on 29 June 2010. 5. Facts About Immunisation. Available at www.doh.gov.za/docs/factsheets/immunise/facts.html. Accessed on 3 June 2010. 6. Tuberculosis: Infections: Merck Manual Home Edition. Available at www.merck.com. Accessed on 25 June 2010. 7. Tuberculosis (TB): Mycobacteria: Merck Manual Professional. Available at www.merck.com. Accessed on 30 June 2010. 8. Polio: Viral Infections: Merck Manual Home Edition. Available at www.merck.com. Accessed on 25 June 2010. 9. Poliomyelitis: Enteroviruses: Merck Manual Professional. Available at www.merck.com. Accessed on 30 June 2010. 10. O'Ryan M. Rotarix TM (RIX4414): an oral human rotavirus vaccine. Expert Rev. Vaccines 2007; 6(1):11-19. 11. Rotavirus Infection: Viral Infections: Merck Manual Home Edition. Available at www.merck.com. Accessed on 25 June 2010. 12. Modarres S, Modarres S, Oskoii NN. Rotavirus Infection in infants and young children with acute gastroenteritis in the Islamic Republic of Iraq. Eastern Mediterranean Health Journal 1995; 1: 210-214. 13. Berkow R, Fletcher AJ eds. The Merck Manual of Diagnosis and Therapy. Merck \& Co, New Jersey. Fifteenth Edition. 1990:pp 780-782; 957. 14. Parashar UD, Hummelman EG, Bresee JS, Miller MA, Glass RI. Global Illness and Deaths Caused by Rotavirus Disease in Children. Emerg Infect Dis 2003; 9(5): 565-572. 15. Solarsh G, Goga A. South African Health Review 2003/2004. Chapter 8: Child Health; 101-128. Available from: http://www.hst.org.za/publications/423 Accessed 3004 2009. 16. Diphtheria: Bacterial Infections: Merck Manual Home Edition. Available at www.merck.com. Accessed on 25 June 2010. 17. Immunization Action Coalition: Diphtheria: Questions and Answers. Available at www.immunize.org. Accessed on 06 July 2010. 18. Tetanus: Bacterial Infections: Merck Manual Home Edition. Available at www.merck.com. Accessed on 25 June 2010. 19. Pertussis: Bacterial Infections: Merck Manual Home Edition. Available at www.merck.com. Accessed on 25 June 2010. 20. Haemophilus influenzae Infections: Bacterial Infections: Merck Manual Home Edition. Available at www.merck.com. Accessed on 25 June 2010. 21. Common Vaccinations: Immunization: Merck Manual Home Edition. Available at www.merck.com. Accessed on 25 June 2010. 22. Introduction: Hepatitis: Merck Manual Home Edition. Available at www.merck.com. Accessed on 25 June 2010. 23. Pneumococcal Infections: Bacterial Infections: Merck Manual Home Edition. Available at www.merck.com. Accessed on 25 June 2010. 24. Measles: Viral Infections: Merck Manual Home Edition. Available at www.merck.com. Accessed on 25 June 2010. 25. Measles: Other Viruses: Merck Manual Professional.. Available at www.merck.com. Accessed on 30 June 2010.

\section{○ aspen Hastherae, wo care.}

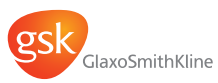

Marketed by Aspen Pharmacare www.aspenpharma.com Hotline 0800118088

GlaxoSmithKline South Africa (Pty) Ltd. (Co. Reg. No. 1948/030135/07). 57 Sloane Street, Bryanston, 2021. Tel: +2711745 6000. Fax: +2711745 7000. Marketed by Aspen Pharmacare, Building 12, Healthcare Park, Woodlands Drive, Woodmead, 2191. www.aspenpharma.com. Medical Information Hotline 0800118088.

A11680 ROT/0710/139 